\title{
Early evolution of the Proto-Andean margin of South America
}

\author{
C. W. Rapela Centro de Investigaciones Geológicas, Universidad Nacional de La Plata, Calle 1 No. 644, 1900 La Plata, Argentina \\ R. J. Pankhurst British Antarctic Survey, Cambridge CB30ET, United Kingdom \\ C. Casquet \\ E. Baldo - Departamento de Petrología y Geoquímica, Universidad Complutense, 28040 Madrid, Spain \\ J. Saavedra CSIC, Instituto de Agrobiología y Recursos Naturales, 37071 Salamanca, Spain \\ C. Galindo Departamento de Petrología y Geoquímica, Universidad Complutense, 28040 Madrid, Spain
}

\section{ABSTRACT}

From a detailed study of a $500 \mathrm{~km}$ transect in the Sierras Pampeanas, central-west Argentina, two pre-Silurian tectono-magmatic episodes are recognized and defined, each culminating in micro-continental collisions against the proto-Andean margin of Gondwana. The Pampean orogeny started in Early Cambrian time with short-lived subduction, indicated by ca. $535 \mathrm{Ma}$ calc-alkaline granitoids. Following Pampean terrane collision, burial to granulite facies conditions (ca. 9 kbar) generated widespread migmatites and ca. 520 Ma highly peraluminous granites in the Eastern Sierras Pampeanas. After brief quiescence, a second major episode, the Famatinian orogeny, started with subduction ca. $490 \mathrm{Ma}$, forming a wide continental arc and ensialic backarc basin. This heralded the approach of Laurentia to Gondwana, during which the Precordillera terrane separated from the southern Appalachian region, finally colliding with Gondwana in Silurian-Devonian time.

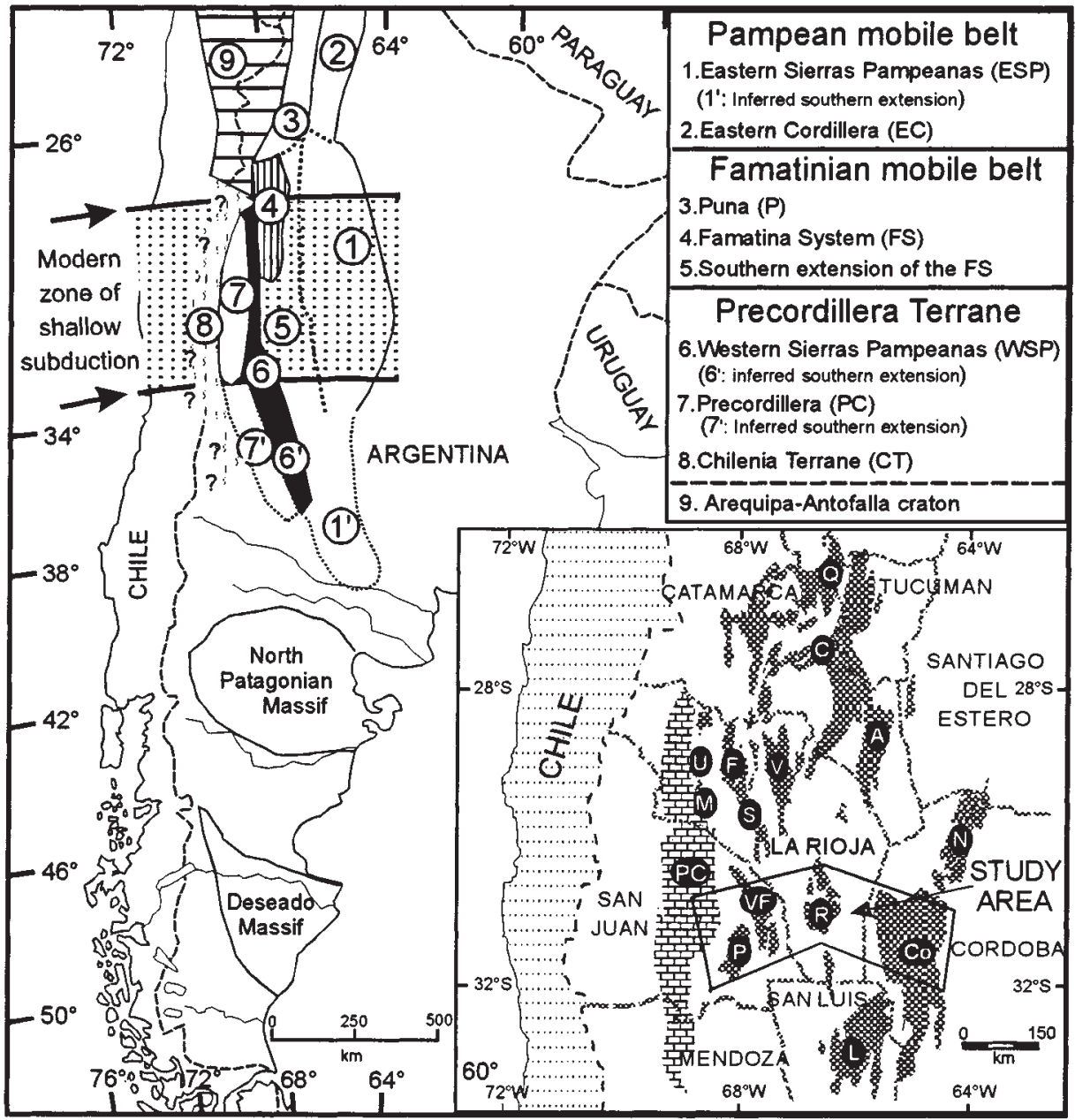

Figure 1. Early Paleozoic geological provinces in southern Andes, disclosed by back-thrusting above Miocene "flat-slab" subduction. Principal sierras in this segment are: Q: Quilmes; C: Capillitas; A: Ancasti; F: Famatina; V: Velasco; U: Umango; M: Maz; S: Sañogasta; N: Norte de Córdoba; Co: Córdoba; L: San Luis; R: Llanos de la Rioja; VF: Valle Fértil; P: Pie de Palo; PC: Precordillera.

\section{INTRODUCTION}

The evolution of the Gondwana margin proposed here is based on new geochemical, isotopic, petrological, and sedimentological data from a $500 \mathrm{~km}$ traverse across the Eastern Sierras Pampeanas and Precordillera (Fig. 1). Pre-Silurian metamorphic and magmatic history is inferred from (1) dating by conventional U-Pb on abraded zircons, U-Pb SHRIMP analyses, and whole-rock $\mathrm{Rb}-\mathrm{Sr}$ and $\mathrm{K}-\mathrm{Ar}$, (2) thermo-barometry based on microprobe mineral analyses, and (3) $\mathrm{Nd}$ and $\mathrm{Sr}$ isotopes, and major and trace element geochemistry of the magmatic suites. Detailed data and interpretation have been presented for the Sierras de Córdoba (Rapela et al., 1998) and Sierras de La Rioja (Pankhurst et al., 1998).

\section{THE GONDWANA MARGIN}

Geological and paleontological evidence indicating that the Argentine Precordillera is a Laurentian terrane has revolutionized ideas about the proto-Andean margin of South America (Dalziel, 1997, and references therein). The exotic origin of the Precordillera is now widely accepted, although the timing of accretion and the associated geotectonic models remain controversial (e.g., Dalla Salda et al., 1992; Astini et al., 1995; Dalziel, 1997; Benedetto, 1998). Evolution of the Gondwana margin immediately prior to accretion is also poorly constrained.

Paleozoic provinces at $27^{\circ}-33^{\circ} \mathrm{S}$ may be divided into those related to Early to Middle Cambrian accretion (the Pampean mobile belt), and those associated with Ordovician subduction (the Famatinian mobile belt) and later collision of an exotic terrane (the Precordillera terrane). Our data lead to a more restricted definition of Pampean and Famatinian events and their duration than the less restricted use of some authors. The Pampean mobile belt includes the Eastern Sierras Pampeanas and Eastern Cordillera (Fig. 1). It is mostly composed of medium to low pressure $(P)$ and temperature $(T)$, high-grade metamorphic rocks and anatectic granites, partially remobilized and intruded by Ordovician-Carboniferous granitoids. The Famatinian mobile belt, encompassing the Puna and the Famatina System, consists of low to high grade, low $P-T$ metamorphic rocks, backarc sediments and ophiolites, and widespread Ordovician magmatic arc rocks. The Precordillera terrane (Precordilleran terrane of Astini et al., 1995) is essentially equivalent to the 
Cuyania terrane of Ramos et al. (1996), and consists of metamorphic basement partly covered by Cambrian-Ordovician carbonate rocks. In the Precordillera, the latter contain typical Laurentian faunas (see Benedetto, 1998) and subsequent siliciclastic units that extend into the upper Paleozoic; a Grenville age for their unexposed basement has been inferred from xenoliths in Miocene volcanic rocks $(1102 \pm 6 \mathrm{Ma}, \mathrm{U}-\mathrm{Pb}$ zircon, Kay et al., 1996). Exposed Grenville-age basement occurs both east and west of the Precordillera (see below).

The Late Proterozoic-Silurian evolution of the Gondwana foreland is compared to that of the Precordillera terrane in Figure 2.

Supercontinent Break-up: Opening of the Puncoviscan and Southern Iapetus Oceans

Break-up of the latest Precambrian Pannotia supercontinent produced continental terranes that were accreted to Laurentia and Gondwana in early Paleozoic collisions; recently reviewed geological evidence along the conjugate margins indicates a latest Precambrian to Early Cambrian age for the rift-drift transition (Dalziel, 1997). The Puncoviscana Formation of western Argentina is seen as the South American proximal counterpart of deep-marine passive margin sequences. Inferred sequential opening of the Puncoviscan and Southern Iapetus oceans (the

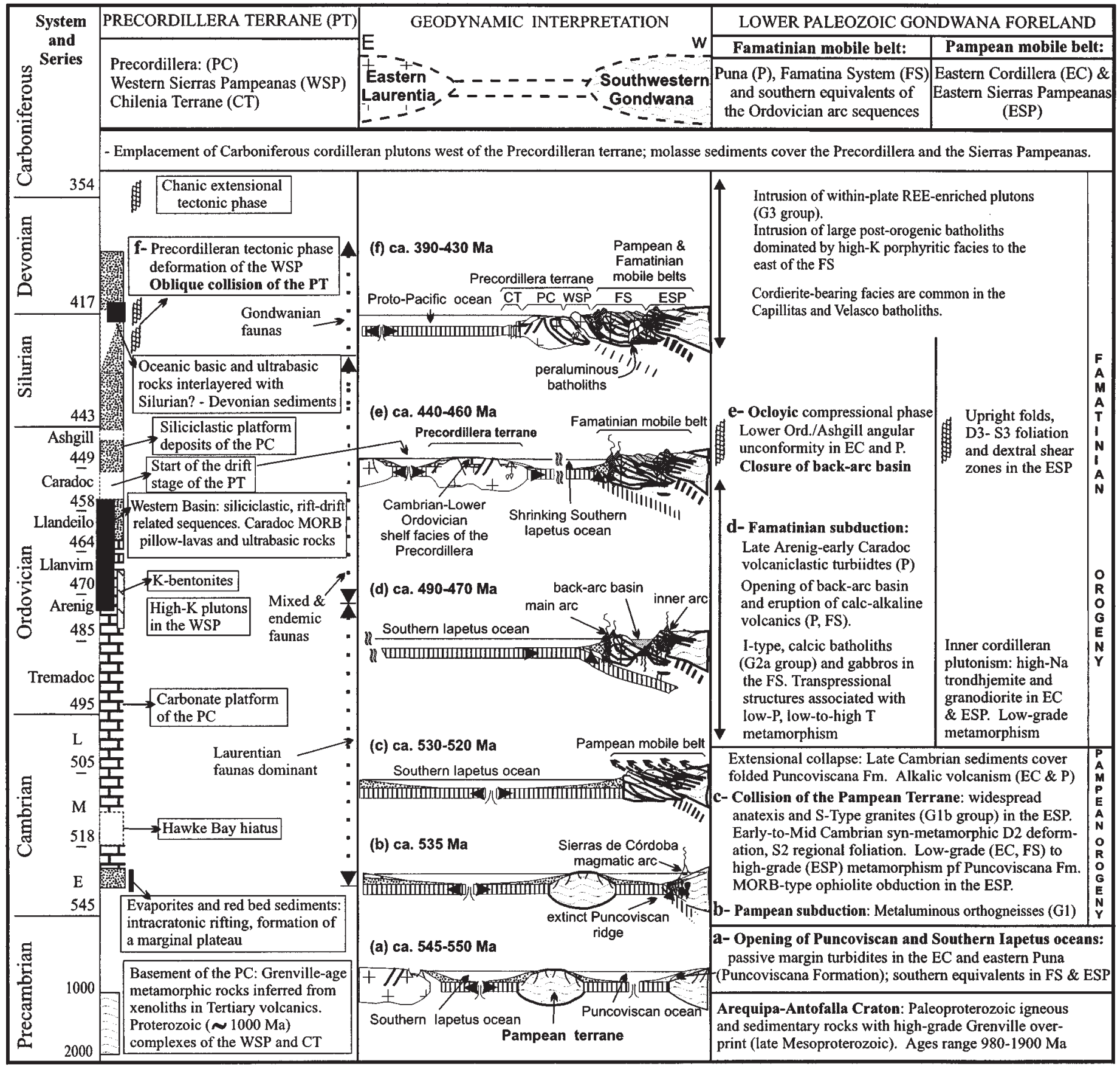

Figure 2. Sequence of Paleozoic orogenic events in proto-Andean margin of South America. Tectono-magmatic evolution and geochronological control for Gondwana are from Pankhurst et al. (1998) and Rapela et al. (1998); time scale of Gradstein and Ogg (1996). Sedimentary sequences, faunas, and tectonic phases in Precordillera are simplified from Astini et al. (1995), Benedetto, (1998), and Keller et al. (1998); plate tectonic stages of Precordillera terrane are after Keller et al. (1998). Acronyms as in Figure 1. 
result of a spreading-center shift?) left "dead" oceanic crust between a detached continental block, the Pampean terrane, and the Gondwana margin (Figs. 2a and 3).

\section{Pampean Orogeny: Early Cambrian Subduction and Terrane Collision}

The proto-Andean margin of Gondwana changed from passive to active in Early Cambrian time, leading to closure of the Puncoviscan ocean (Fig. 2b). The youngest trace fossils in the Puncoviscana Formation are Tommotian (Durand, 1996), ca. 530-534 Ma. These date the last passive margin deposits, succeeded by a thick accretionary prism. A subduction-related belt of metaluminous calc-alkaline granitoids (G1a) and dacite-rhyolite was emplaced along the eastern part of the Eastern Sierras Pampeanas (Lira et al., 1996; Rapela et al., 1998); in the Sierras de Córdoba, this is dated as $530 \pm 4 \mathrm{Ma}$ by $\mathrm{U}-\mathrm{Pb}$ on abraded zircons from three plutonic units (Rapela et al., 1998). Intrusion was followed by crustal thickening and burial to granulite facies conditions $(P=8.6 \pm 0.8 \mathrm{kbar}$, $\left.T=810 \pm 50{ }^{\circ} \mathrm{C}\right)$. A clockwise $P$ - $T$-time path is inferred, producing regional migmatites during peak thermal conditions of $P=5.7 \pm 0.4 \mathrm{kbar}$, $T=820 \pm 25^{\circ} \mathrm{C}$; dated as $522 \pm 8 \mathrm{Ma}$ by a U-Pb SHRIMP age on monazite. Immediately following this, strongly peraluminous, cordierite- and sillimanite-bearing granites and associated cordierites were generated by low- $P$ anatexis of metasediments $(P=3.9 \pm 0.6 \mathrm{kbar}, T=684 \pm$ $60{ }^{\circ} \mathrm{C}$ ); an 18 point $\mathrm{Rb}$-Sr whole-rock isochron gave $523 \pm 4 \mathrm{Ma}, \mathrm{Sr}_{\mathrm{i}}=0.7136$, mean square of weighted deviates $(\mathrm{MSWD})=2.0$; and $\mathrm{U}-\mathrm{Pb}$ on abraded zircons gave $523 \pm 2 \mathrm{Ma}$. This orogeny is interpreted as due to Early to Middle Cambrian collision between the semiautochthonous Pampean terrane and Gondwana (Rapela et al., 1998). Middle Cambrian deformation of the Puncoviscana Formation north of $27^{\circ} \mathrm{S}$ (Aceñolaza et al., 1990; Bahlburg and Hervé, 1997) is ascribed to the Pampean orogeny. SHRIMP ages of 600-1400 Ma for inherited zircon from both high-grade metapelites and peraluminous granites suggest provenance from Middle to Late Proterozoic sources.

\section{Ordovician Subduction on the Gondwana} Margin vs. Break-up of Eastern Laurentia

After Pampean terrane accretion, the protoPacific margin became passive at this latitude until Early Ordovician time: There was no orogenic activity and little granitoid emplacement in the Sierras Pampeanas between 515 and $490 \mathrm{Ma}$. The Famatinian magmatic arc was initiated in earliest Ordovician time and affected all geological provinces in southwestern Gondwana. An inner arc of sparse high-Al trondhjemites was emplaced at $496 \pm 2$ Ma in the Pampean foreland of the Sierras de Córdoba; a new cordilleran arc of calcic granitoids was initiated to the west at

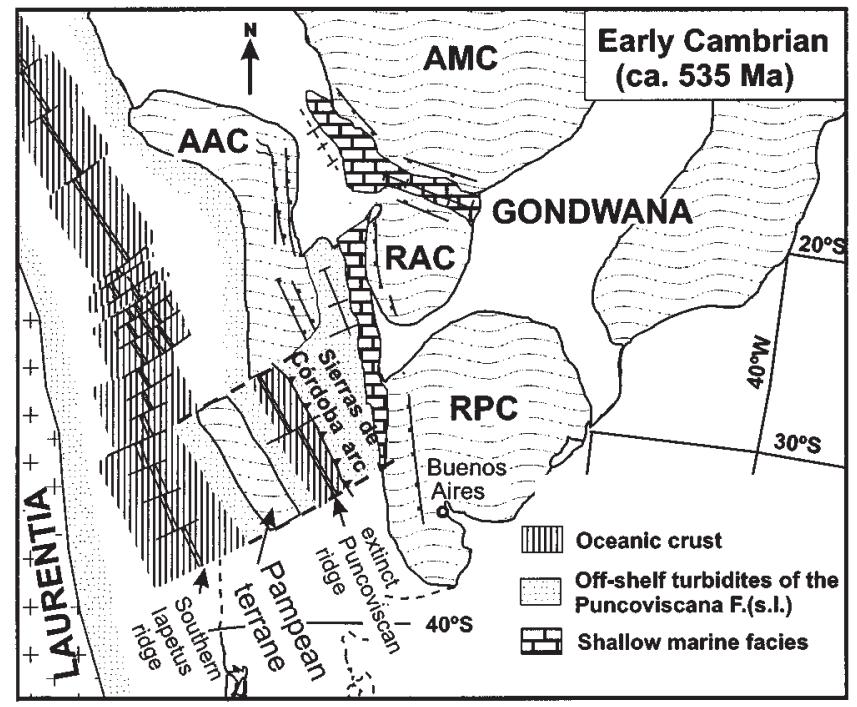

Figure 3. Early Cambrian reconstruction of southwestern Gondwana. Eastern Laurentia and South America were initially amalgamated by Grenvillian orogens (Pannotia supercontinent, Dalziel, 1997), with latest Precambrian to Early Cambrian breakup. The Neoproterozoic and Early Cambrian sediment distribution in South America is modified from Durand (1996). Cratons: AAC, Arequipa-Antofalla; AMC, Amazonia; RAC, Río Apa; RPC, Río de la Plata.

$492 \pm 6 \mathrm{Ma}$ and lasted until ca. $450 \mathrm{Ma}$ (U-Pb zircon and Rb-Sr whole rock, Rapela et al., 1998; Pankhurst et al., 1998). The granitoids intruded the westernmost passive margin sequences overlying the Pampean basement; they exhibit identical Sm-Nd crustal residence ages to those of the Cambrian plutonic rocks of the Sierras de Córdoba (1550-1750 Ma), significantly older than those of the Precordillera terrane (Pankhurst et al., 1998). The Famatinian magmatic arc was clearly continental, not an island arc.

A wide backarc basin filled by TremadocianLlanvirnian shallow-marine volcaniclastic and/or volcanic rocks opened between the inner and main arcs (Fig. 2d). It was floored by oceanic crust in the southern Puna (Bahlburg and Hervé, 1997), and opened progressively southward, reaching the Sierras de San Luis at $33^{\circ} \mathrm{S}$ (Sims et al., 1998). The basin closed during the Late Ordovician Ocloyic tectonic phase, producing westward thrusting and mylonite belts in the high-grade Pampean basement of the Sierras de Córdoba (D3 deformation). Pegmatites associated with the dextral shear zones of this stage yield K-Ar ages of 435-447 Ma (Rapela et al., 1998). North of $27^{\circ} \mathrm{S}$, the Eastern Cordillera rode over the eastern edge of the Puna and the Arequipa-Antofalla craton, together with obducted ophiolites (Balhburg and Hervé, 1997, and references therein).

Evolution of the Gondwana foreland at this time sharply contrasts with that of the obviously exotic Precordillera (Fig. 2). The Precordillera has a typical passive margin, Early CambrianArenigian, carbonate shelf sequence, which resembles that of the southern Appalachians and similarly overlies Grenville-age metamorphic rocks (Dalla Salda et al., 1992; Kay et al. 1996). The Grenvillian age of Western Sierras Pampeanas orthogneisses considered part of the Precordillera terrane basement is established by $\mathrm{Rb}$-Sr whole-rock isochrons of $1030 \pm 30 \mathrm{Ma}$, $\mathrm{Sr}_{\mathrm{i}}=0.70258 \pm 0.00028$ (Sierra de Umango, Varela et al., 1996) and $1021 \pm 12 \mathrm{Ma}, \mathrm{Sr}_{\mathrm{i}}=$ $0.7045 \pm 0.0003$ (Sierra de Pie de Palo, Pankhurst and Rapela, 1998).

The Grenvillian rocks of the Sierra de Pie de Palo were intruded by Ordovician high-K quartz monzonite and monzogranite $(481 \pm 6 \mathrm{Ma}$, SHRIMP U-Pb zircon, Pankhurst and Rapela, 1998), which we tentatively associate with volcanism represented by K-bentonites interbedded with the Arenig-Llanvirn carbonate units of the Precordillera (Huff et al., 1995). This magmatism was coeval with extensional collapse of the Precordillera carbonate shelf, indicated by Arenigian mass-flow turbiditic deposits and giant olistoliths, and culminating with eruption of Caradocian mid-ocean ridge basalts and ultramafic rocks (Fig. 2; Astini et al., 1995). This can be seen as the start of the drift stage of the Precordillera terrane, following its separation from eastern Laurentia. Ashgillian closure of the Gondwana margin backarc basin and Ocloyic tectonism (Fig. 2e; Bahlburg and Hervé, 1997) may have been related to accelerated convergence during and following the Precordilleran rift-drift transition on the opposite margin of the southern Iapetus Ocean; the Ocloyic phase may not be causally related to accretion of the Precordillera terrane, as often supposed. 


\section{Docking of the Precordillera Terrane}

Timing of the collision of the Precordillera terrane with Gondwana is still unresolved. Despite many other differences, most recent geodynamic models have considered that this occurred during the Middle Ordovician Famatinian orogeny (Dalla Salda et al., 1992; Astini et al., 1995; Dalziel, 1997; Ramos et al., 1996). However, there is increasing evidence for later accretion, during Silurian or Early Devonian time (Fig. 2f): (1) There is no evidence for Late Cambrian subduction on the Gondwana margin, which started ca. $490 \mathrm{Ma}$, leaving little time to close the southern Iapetus Ocean before the Middle Ordovician; (2) reactivation of the Grenvillian basement in the Sierra de Pie de Palo occurred between 432 and $394 \mathrm{Ma}$ (Ar-Ar ages on hornblende and muscovite, Ramos et al., 1996); (3) the first contraction of the Precordillera sedimentary sequences occurred in Upper Silurian-Lower Devonian time (Astini, 1996); (4) the first unequivocal evidence for close proximity of the Precordillera to Gondwana is the early Wenlockian (ca. $425 \mathrm{Ma}$ ) Clarkeia fauna (Benedetto, 1998); and (5) K-Ar chronology shows that east of the main Famatinian arc, intrusion of strongly peraluminous batholiths (Rapela et al., 1992) and formation of transpressional shear zones continued well into Devonian time (Sims et al., 1998). Middle Silurian to Early Devonian accretion of the Precordillera terrane overlaps with that of the postulated Chilenia terrane (Ramos and Basei, 1997), so that the small outcrops from which Chilenia has been identified might really be slivers of the Precordillera terrane basement, displaced westward during the collision, rather than a separate terrane (such an origin for the Frontal Cordillera basement outcrops was considered by Ramos and Basei, 1997).

\section{CONCLUSIONS}

The crustal framework of the Southern Andes was formed during early Paleozoic continental collisions. The first was the Early to Middle Cambrian (530-520 Ma) collision of the Pampean terrane against the newly formed passive margin of Gondwana. Subduction restarted at ca. $490 \mathrm{Ma}$ (Tremadocian?), forming a wide continental arc and an ensialic backarc basin floored by ocean crust. The Precordillera terrane rifted from eastern Laurentia in Early Caradocian time, during closure of the southern Iapetus Ocean. Accretion of this terrane to Gondwana was complex and protracted, starting with closure of the Famatinian backarc basin during the Late Ordovician (440-450 Ma) and concluding with collision in Middle Silurian to Early Devonian time (430 $390 \mathrm{Ma}$ ), together with intrusion of large peraluminous Devonian batholiths.
ACKNOWLEDGMENTS

This work was carried out as part of contract CI1-CT92-0088 from the Commission of the European Communities and was also supported by grant PIP 4148, Consejo Nacional de Investigaciones Científicas y Técnicas, Argentina.

\section{REFERENCES CITED}

Aceñolaza, F. G., Miller, H., and Toselli, A. J., eds., 1990, El Ciclo Pampeano en el Noroeste Argentino: Universidad Nacional de Tucumán, Argentina, 227 p., Serie Correlación Geológica no. 4.

Astini, R. A., 1996, Las fases diastróficas del Paleozoico Medio de la Precordillera del oeste argentino-evidencias estratigráficas: XIII Congreso Geológico Argentino y III Congreso de Exploración de Hidrocarburos, Buenos Aires, Actas V, p. 509-526.

Astini, R. A., Benedetto, J. L., and Vaccari, N. E., 1995, The early Paleozoic evolution of the Argentine Precordillera as a Laurentian rifted, drifted and collided terrane: A geodynamic model: Geological Society of America Bulletin, v. 107, p. 253-273.

Bahlburg, H., and Hervé, F., 1997, Geodynamic evolution and tectonostratigraphic terranes of northwestern Argentina and northern Chile: Geological Society of America Bulletin, v. 109, p. 869-884.

Benedetto, J. P., 1998, Early Palaeozoic brachiopods and associated shelly faunas from western Gondwana: Its bearing on the geodynamic history of the pre-Andean margin, in Pankhurst, R. J., and Rapela, C. W., eds., The Proto-Andean margin of South America: Geological Society [London] Special Publication (in press).

Dalla Salda, L., Cingolani, C. A., and Varela, R., 1992, Early Paleozoic belt of the Andes and southwestern South America: Result of LaurentiaGondwana collision?: Geology, v. 20, p. 617-620.

Dalziel, I. W. D., 1997, Overview. NeoproterozoicPaleozoic geography and tectonics: Review, hypothesis, environmental speculation: Geological Society of America Bulletin, v. 109, p. 16-42.

Durand, F. R., 1996, La transición PrecámbricoCámbrico en el sur de Sudamérica, in Baldis, B., and Aceñolaza, F. G., eds., Early Paleozoic evolution in NW Gondwana: Universidad Nacional de Tucumán, Argentina, Serie Correlación Geológica no. 12, p. 195-205.

Gradstein, F. M., and Ogg, J., 1996, A Phanerozoic time scale: Episodes, v. 19, p. 3-5.

Huff, W. D., Bergström, S. M., Kolata, D. R. Cingolani, C., and Davis, D. W., 1995, Middle Ordovician K-bentonites discovered in the Precordillera of Argentina: Geochemical and paleogeographic implications, in Cooper, J. D., Droser, M. L., and Finney, S. C., eds., Ordovician odyssey: Short papers for the Seventh International Symposium on the Ordovician System: Pacific Section, Society for Sedimentary Geology Book 77, p. 343-349.

Kay, S. M., Orrell, S., and Abruzzi, J. M., 1996, Zircon and whole-rock $\mathrm{Nd}-\mathrm{Pb}$ isotopic evidence for a Grenville age and Laurentian origin for the basement of the Precordillera in Argentina: Journal of Geology, v. 104, p. 637-648.

Keller, M., Buggisch, W., and Lehnert, O., 1998, The stratigraphic record of the Argentine Precordillera and its plate-tectonic background, in Pankhurst, R. J., and Rapela, C. W., eds., The Proto-Andean margin of South America: Geological Society [London] Special Publication (in press).

Lira, R., Millone, H. A., Kirschbaum, A. M., and Moreno, R. S., 1996, Calc-alkaline arc granitoid activity in the Sierra Norte-Ambargasta Ranges, central Argentina: Journal of South American Earth Sciences, v. 10, p. 157-177.

Pankhurst, R. J., and Rapela, C. W., 1998, The protoAndean margin of Gondwana: An introduction, in Pankhurst, R. J., and Rapela, C. W., eds., The Proto-Andean margin of South America: Geological Society [London] Special Publication (in press).

Pankhurst, R. J., Rapela, C. W., Saavedra, J., Baldo, E., Dahlquist, J., Pascua, I., and Fanning, C. M., 1998, The Famatinian magmatic arc in the central Sierras Pampeanas, in Pankhurst, R. J., and Rapela, C. W., eds., The Proto-Andean margin of South America: Geological Society [London] Special Publication (in press).

Ramos, V. A., and Basei, M., 1997, The basement of Chilenia: An exotic continental terrane to Gondwana during the early Paleozoic, in Bradshaw, J. D., and Weaver, S. D., eds., Terrane Dynamics-97: International Conference on Terrane Geology, University of Canterbury, Christchurch, Conference Abstracts: p. 140-143,

Ramos, V. A., Vujovich, G. I., and Dallmeyer, R. D. 1996, Los klippes y ventanas tectónicas preándicas de la Sierra de Pie de Palo (San Juan): Edad e implicaciones tectónicas: XIII Congreso Geológico Argentino y III Congreso de Exploración de Hidrocarburos, Buenos Aires, Actas V, p. 377-391.

Rapela, C. W., Coira, B., Toselli, A., and Saavedra, J., 1992, The lower Paleozoic magmatism of southwestern Gondwana and the evolution of the Famatinian orogene: International Geology Review, v. 34, p. 1081-1142.

Rapela, C. W., Pankhurst, R. J., Casquet, C., Baldo, E., Saavedra, J., and Galindo, E., 1998, The Pampean orogeny of the southern proto-Andes: Evidence for Cambrian continental collision in the Sierras de Córdoba, in Pankhurst, R. J., and Rapela, C. W., eds., The Proto-Andean margin of South America: Geological Society [London] Special Publication (in press).

Sims, J. P., Ireland, T. R., Camacho, A., Lyons, P., Pieters, P. E., Skirrow, R. G., and Stuart-Smith, P. G., 1998, U-Pb, Th-Pb and Ar-Ar geochronology from the southern Sierras Pampeanas, Argentina: Implications for the Palaeozoic tectonic evolution of the western Gondwana margin, in Pankhurst, R. J., and Rapela, C. W., eds., The Proto-Andean margin of South America: Geological Society [London] Special Publication (in press).

Varela, R., López de Luchi, M., Cingolani, C., and Dalla Salda, L., 1996, Geocronología de gneises y granitoides de la Sierra de Umango, La Rioja: Implicancias tectónicas: XIII Congreso Geológico Argentino y III Congreso de Exploración de Hidrocarburos, Buenos Aires, Actas III, p. 519-528.

Manuscript received February 12, 1998

Revised manuscript received May 5, 1998

Manuscript accepted May 18, 1998 